\title{
Association study in siblings and case-controls of serotonin- and oxytocin-related genes with high functioning autism
}

\author{
Johanna Nyffeler ${ }^{1}$, Susanne Walitza ${ }^{1,2}$, Elise Bobrowski ${ }^{1,3}$, Ronnie Gundelfinger ${ }^{1}$ and Edna Grünblatt ${ }^{1,2^{*}}$
}

\begin{abstract}
Background: Autism spectrum disorder (ASD) is heritable and neurodevelopmental with unknown causes. The serotonergic and oxytocinergic systems are of interest in autism for several reasons: (i) Both systems are implicated in social behavior, and abnormal levels of serotonin and oxytocin have been found in people with ASD; (ii) treatment with selective serotonin reuptake inhibitors and oxytocin can yield improvements; and (iii) previous association studies have linked the serotonin transporter (SERT; SLC6A4), serotonin receptor 2A (HTR2A), and oxytocin receptor (OXTR) genes with ASD. We examined their association with high functioning autism (HFA) including siblings and their interaction.
\end{abstract}

Methods: In this association study with HFA children (IQ > 80), siblings, and controls, participants were genotyped for four single nucleotide polymorphisms (SNPs) in OXTR (rs2301261, rs53576, rs2254298, rs2268494) and one in HTR2A (rs6311) as well as the triallelic HTTLPR (SERT polymorphism).

Results: We identified a nominal significant association with HFA for the HTTLPR $s$ allele (consisting of $\mathrm{S}$ and $\mathrm{L}_{\mathrm{G}}$ alleles) $(\mathrm{p}=.040$; odds ratio $(\mathrm{OR})=1.697,95 \% \mathrm{Cl} 1.191-2.204)$ ). Four polymorphisms (HTTLPR, HTR2A rs6311, OXTR rs2254298 and rs53576) in combination conferred nominal significant risk for HFA with a genetic score of $\geq 4$ $(\mathrm{OR}=2.09,95 \% \mathrm{Cl} 1.05-4.18, \mathrm{p}=.037)$. The resulting area under the receiver operating characteristic curve was 0.595 $(p=.033)$.

Conclusions: Our findings, combined with those of previous reports, indicate that ASD, in particular HFA, is polygenetic rather than monogenetic and involves the serotonergic and oxytocin pathways, probably in combination with other factors.

Keywords: Autism spectrum disorder, High functioning autism, Oxytocin receptor, Polymorphism, Serotonin receptor $2 \mathrm{~A}$, Serotonin transporter

\section{Background}

Autism spectrum disorder (ASD) is a neurodevelopmental disorder characterized by impairments in social interactions and communication and by repetitive behaviors $[1,2]$. An ASD diagnosis can be made very early in childhood, but the disorder is a lifelong condition. The prevalence is estimated to be $0.6-1.0 \%$ [3-6], with a male:female

\footnotetext{
* Correspondence: edna.gruenblatt@kjpdzh.ch

'University Clinics of Child and Adolescent Psychiatry (UCCAP), University of

Zurich, Thurgauerstr. 39, CH-8050 Zurich, Switzerland

${ }^{2}$ Neuroscience Center Zurich, University of Zurich and ETH Zurich, Zurich,

Switzerland

Full list of author information is available at the end of the article
}

ratio of 4:1 [6]. Twin studies give an estimated heritability of 70-90\% [7-10], implicating genetics as a main factor in the etiology, in addition to environmental factors. Some ASD cases are caused by single gene defects [11-13], but for most cases, the genetic causes are unknown.

Both the serotonergic and oxytocinergic systems seem to play a role in ASD and social behaviors [14]. The serotonergic system is of special interest in autism for several reasons: (i) In up to $30 \%$ of people with ASD, elevated whole blood serotonin (5-HT) levels have been reported [15]; (ii) ASD-related sensory motor behaviors are increased after depletion of tryptophan, a precursor in 5-HT synthesis [16]; (iii) reduced serotonin receptor 2A 
(HTR2A) and serotonin transporter (SERT, also known as 5 -HTT) binding in certain brain regions of people with ASD has been identified [17-19]; (iv) selective serotonin reuptake inhibitors (SSRIs) can improve abnormal reciprocal social interaction and repetitive behaviors in some cases [20-23]; and (v) several polymorphisms in the HTR2A gene (NCBI Gene ID: 3356) and the SERT gene (also known as SLC6A4; NCBI Gene ID: 6532) have suggested association with ASD [24-29]. In the following, we focus on these two candidate genes: The promoter sequence of SERT contains a polymorphic region (HTTLPR) with a short allele $(\mathrm{S})$ and a long allele $(\mathrm{L})$ that is $44 \mathrm{bp}$ longer and can contain an additional single nucleotide polymorphism (SNP) (rs25531), making the locus triallelic $\left(\mathrm{L}_{\mathrm{A}}, \mathrm{L}_{\mathrm{G}}\right.$ and $\left.\mathrm{S}\right)$ [30,31]. These polymorphisms affect SERT expression, with the $\mathrm{S}$ and $\mathrm{L}_{\mathrm{G}}$ alleles (here denoted collectively as the $\mathrm{s}$ allele, while $\mathrm{L}_{\mathrm{A}}$ as the 1 allele) reducing transcriptional efficiency [30,31]. Still, some inconsistent results appear with $\mathrm{s}$ allele or 1 allele associations with ASD depending on ethnicity or diagnostic inclusion as found in a meta-analysis [24]. Association studies of HTR2A have concentrated mostly on three non-coding SNPs (rs6311, rs6313, rs6314) [26-28,32].

Similarly, the oxytocinergic system has attracted attention for similar reasons: (i) Low plasma oxytocin levels have been observed in autistic boys [33,34]; (ii) elevated oxytocin precursor levels in ASD children have been reported [33]; and (iii) administration of oxytocin has improved retention of social information and decreased repetitive behaviors in ASD as well as in high functioning autism (HFA) [35-38]. Nonetheless, genetic studies have mainly failed to associate the oxytocin gene with autism; however, several studies have reported an association with the oxytocin receptor gene (OXTR; NCBI Gene ID: 5021), although inconsistently [39-43]. In particular the OXTR polymorphism: rs2301261, rs53576, rs2254298 and rs2268494, were studied in ASD and social behavior [40,42-44].

Recent reports have indicated some interactions among 5-HT, serotonergic components, and oxytocin [14,45,46]. In the first report by Hammock et al. [45], plasma oxytocin and 5-HT levels were negatively correlated with each other, and this relationship was most prominent in children under age 11 years. Thanseem and colleagues [46], on the other hand, found that transcription factor-like specificity protein 1 expression in brains of ASD participants increased in parallel with dysregulation of the transcription of HTR2A (down-regulation) and OXTR (up-regulation), which might further reveal downstream pathways mediating brain developmental disorders. Moreover, Dolen et al. [14] could demonstrate in mice models that the rewarding properties of social interactions require the coordinated activity of oxytocin and 5-HT in the nucleus accumbens, and this oxytocininduced synaptic plasticity requires activation of nucleus accumbens serotonin receptor $1 \mathrm{~B}$.
Because previous association studies of SERT, HTR2A, and $O X T R$ have led to controversial findings, but the mentioned genes seem to interact with one another, we attempted to replicate these associations analyzing ASD children (high functioning), their siblings, and controls with no clinical diagnoses. In contrast to other studies, we included only patients with HFA in our study, eliminating confounding parameters such as IQ. Sibships transmission analysis was included to enhance further the case-control findings. Additionally, we tested for interaction among the three genes, since these were reported to be involved in ASD and even further to interact with each other, on the assumption that neurodevelopmental disorders are polygenetic rather than monogenetic.

\section{Methods}

\section{Participants}

The study was approved by the ethics committee of the Canton Zurich, Switzerland (E-36/2009). Parents of all participants gave their written consent after being informed about the aim of the study. All participants (76 with HFA, 78 siblings, and 99 controls) were Caucasians between 5 and 17 years of age collected in the Department of Child and Adolescent Psychiatry at the University of Zurich. In all patients diagnosis was confirmed using the Autism Diagnosis Observation Schedule [47] and the Autism Diagnosis Interview [48]. Inclusion criteria for all children with high-functioning ASD (64 males and 12 females) was IQ of at least 80 from at least one of two IQ tests (see below) according to strict HFA definition $[49,50]$ and all met the International Statistical Classification of Diseases and Related Health Problems, 10th Revision (ICD-10) [51] criteria for pervasive developmental disorder, including three with childhood autism, 27 with atypical autism, and 46 with Asperger syndrome. Persons with neurological disorders including epilepsy or known genetic diseases linked to autism were excluded.

The siblings of the ASD group (33 males and 45 females) did not have an ASD diagnosis or other severe psychiatric disorders according to screening questionnaires (see below). For the control group, only children without any clinical diagnosis were included in the study (77 males and 22 females).

Additionally, all participants were screened for psychopathology with the following parent reports: Child Behaviour Checklist [52]; Social Responsiveness Scale [53]; Social Communication Questionnaire [54]; Conners [55]; and the German ADHD rating scale, FBB-HKS [56]. Intelligence was measured with the Snijders-Oomen Non-Verbal Intelligence Test 5.5-17 [57] and the Culture Fair Test [58]. Age and IQ distribution for the different study groups is listed in Table 1. 
Table 1 Distribution of age, sex, and IQ for each study group

\begin{tabular}{llcccc}
\hline & & Mean & SD & Range & Total \\
\hline Age (in y) & ASD & 11.24 & 3.10 & $5-17$ & 76 \\
& Siblings* & 10.53 & 3.25 & $6-17$ & 78 \\
& Controls & 11.77 & 3.01 & $6-17$ & 99 \\
\multirow{4}{*}{ Q, SON } & ASD & 108.68 & 16.03 & $80-140$ & 75 \\
& Siblings & 109.75 & 12.36 & $82-135$ & 77 \\
& Controls & 112.19 & 12.53 & $86-140$ & 99 \\
\multirow{2}{*}{ Q, CFT } & ASD & 105.16 & 13.88 & $70-145$ & 68 \\
& Siblings & 104.55 & 10.65 & $85-142$ & 73 \\
& Controls & 106.71 & 10.96 & $85-133$ & 97 \\
\hline \multirow{6}{*}{ Sex } & ASD & Male & Female & Ratio (M/F) & Total \\
& Siblings ${ }^{*+}$ & $33(42.3)$ & $45(57.7)$ & 0.733 & 78 \\
& Controls & $77(77.8)$ & $22(22.2)$ & 3.50 & 99 \\
\hline
\end{tabular}

Abbreviations: $A S D$ autism spectrum disorder, $S D$ standard deviation, SON Snijders-Oomen Non-Verbal Intelligence Test 5.5-17, CFT Culture Fair Test, $M$ Male, $F$ Female.

Statistical analysis was conducted using $\mathrm{X}^{2}$ tests. ${ }^{*} \mathrm{p}<.05$ versus controls; ${ }^{+} \mathrm{p}<.05$ versus ASD.

\section{Genotyping analysis}

Saliva samples for DNA isolation were collected from all recruited individuals using the Oragene DNA kit (DNA Genotek; Kanata, Canada). DNA was isolated from saliva according to the manufacturer's protocol (Oragene $^{\mathrm{TM}}$ DNA Purification Protocol, DNA Genotek). For rs2301261, rs2254298, rs2268494, and rs6311 (Assay ID: C_15756091_30; C_15981334_10; C_15874471_10 and C_8695278_10, respectively), genotyping was performed using TaqMan ${ }^{\bullet}$ SNP Genotyping Assays (Applied Biosystems; Foster City, CA, USA). PCR was carried out on a CFX384 $^{\text {тм }}$ Real-Time System (Bio-Rad; Hercules, CA, USA) in a $5 \mu \mathrm{l}\left(10 \mu \mathrm{l}\right.$ for rs6311) volume using TaqMan ${ }^{\circledR}$ $2 \times$ Universal PCR Master Mix No AmpErase ${ }^{\bullet}$ UNG (Applied Biosystems) and $10 \mathrm{ng}$ (22.5 ng for rs6311) of DNA. Initial enzyme activation was carried out at $95^{\circ} \mathrm{C}$ for 10 min, followed by 40 cycles at $92^{\circ} \mathrm{C}$ for $15 \mathrm{~s}$ and $60^{\circ} \mathrm{C}$ for $1 \mathrm{~min}$.

For rs25531 and HTTLPR analysis, the restriction fragment length polymorphism method was used. Amplification was carried out on a CFX384 $4^{\mathrm{Tm}}$ Thermal Cycler (Bio-Rad) in a $10 \mu \mathrm{l}$ (rs25531) or $25 \mu \mathrm{l}$ (HTTLPR) volume using GoTaq ${ }^{\circ}$ Green Master Mix 2× (Promega; Madison, WI, USA).

For rs25531, the same primers as described previously were used [59]. PCR conditions were an initial denaturation at $95^{\circ} \mathrm{C}$ for $2 \mathrm{~min}$, followed by 40 cycles at $95^{\circ} \mathrm{C}$ for $30 \mathrm{~s}$, $64^{\circ} \mathrm{C}$ for $40 \mathrm{~s}$, and $72^{\circ} \mathrm{C}$ for $40 \mathrm{~s}$ with a final extension at $72^{\circ} \mathrm{C}$ for $5 \mathrm{~min}$. The PCR product was digested overnight at $37^{\circ} \mathrm{C}$ with $10 \mathrm{U}$ BamHI (Fermentas; Burlington, Canada) in a $20 \mu \mathrm{l}$ volume containing $2 \mu \mathrm{l}$ of the corresponding enzyme buffer. Fragments were visualized on a $3 \%$ agarose gel. The fragment size of the undigested $G$ allele is $340 \mathrm{bp}$ whereas the A allele is restricted to bands of 110 and $230 \mathrm{bp}$.

For HTTLPR, the primer sequences were $5^{\prime}$-TGC CGC TCT GAA TGC CAG CAC-3' and 5'-GGG ATT CTG GTG CCA CCT AGA CG-3'. PCR conditions were similar to those for rs53576, but only 30 cycles were carried out at $95^{\circ} \mathrm{C}$ for $45 \mathrm{~s}, 66.5^{\circ} \mathrm{C}$ for $45 \mathrm{~s}$, and $72^{\circ} \mathrm{C}$ at $1 \mathrm{~min}$. Fifteen microliters of PCR product were run on a $3 \%$ agarose gel to distinguish the $\mathrm{L}$ allele (463 bp) and $\mathrm{S}$ allele (419 bp). The remaining PCR product was digested similarly as described above but with $20 \mathrm{U}$ MspI (New England Biolabs, Ipswich, MA, USA). Visualization on 3\% agarose gel allowed distinction of the $\mathrm{G}$ allele (bands of $61,66,162$, 174 , and $292 \mathrm{bp}$ ) from the A allele (61, 66, 292, and $336 \mathrm{bp})$ of rs25531.

\section{Statistical analysis}

Each study group and the total sample were tested for deviation from Hardy-Weinberg equilibrium for all polymorphisms, and no significant departures were found (see Additional file 1: Table S1). Differences in genotype, allele, and carrier frequencies among the groups (HFA, controls, siblings) as well as between two HFA subgroups (atypical autism and Asperger autism) and the control group were tested with the $X^{2}$ test. A sibship disequilibrium test was performed for each polymorphism according to Horvath and Laird [60].

Gene-gene interactions were studied by comparing each combination of two polymorphisms. For each combination, a three-dimensional contingency table with "polymorphism $1 \times$ polymorphism $2 \times$ study group" was built, and a three dimensional $\chi^{2}$ test was performed. All analyses were done with Matlab version 7.10.0 (MathWorks).

Additionally, a receiver operating characteristic (ROC) curve analysis was performed for the various combinations of genetic scores sums, simulating their polygenetic effects on the risk for ASD [61]. Genetic scores attributed to the allelic variations are listed in Additional file 1: Table S2. The area under the curve and its significance were calculated using SPSS version 20 (IBM Corp.).

The nominal significance threshold was set to $5 \%$ and the adjusted significance according Bonferroni for multiple testing was set to $0.8 \%$. Power analysis was performed using $G^{*}$ Power version 3.1.6 [62,63].

\section{Results}

Association of single SNPs with autism diagnosis

To investigate whether oxytocinergic and serotonergic system genes are associated with HFA, 253 children 
were genotyped for polymorphisms in the OXTR, $H T R 2 A$, and SERT. Genotype and minor allele frequencies for all six polymorphisms are summarized in Table 2.

HTTLPR triallelic polymorphism allele frequencies were nominal significantly associated with Asperger diagnosis $(\mathrm{p}=.040$; odds ratio $(\mathrm{OR})=1.697(95 \%$ CI 1.191-2.204)) with the s allele as a risk allele (Table 3). The absolute genotype frequencies for the Asperger group were 17, 23, and 6 for ss, sl, and ll genotypes, respectively, for a relative s allele frequency of 0.619 for the Asperger group compared to 0.490 in the control group. Furthermore, merging 1 carriers led to a trend for association $(\mathrm{p}=.073$; OR $=1.998$ (95\% CI 1.2342.763)). No association of the HTR $2 A$ and OXTR with autism was observed.

Forty "mixed" sibships were included (sibships with affected and unaffected siblings). No significant transmission disequilibrium was detected for any of the tested polymorphisms (Table 4).
Analysis of gene-gene interactions and the polygenetic risk for ASD

Testing for gene-gene interactions by a $X^{2}$-test revealed nominal significant association of HTTLPR and HTR2A (rs6311) with ASD, as well as of the two OXTR SNPs rs53576 and rs2268494 (Additional file 1: Table S3). Three SNPs on the OXTR showed strong linkage disequilibrium; between rs2301261 and rs2254298 ( $\mathrm{p}=4.58 \mathrm{E}-11)$ and between rs2254298 and rs2268494 ( $\mathrm{p}=.005)$; probably causing high transmission of these variant combinations.

Since there is evidence in the literature for the involvement of oxytocinergic and serotonergic systems and their interactions with one another, we investigated the polygenetic gene scores of these variants and the risk for HFA. The strongest result for a polygenetic risk was with the combination of the polymorphisms HTTLPR, HTR2A rs6311, and OXTR rs2254298 and rs53576 (for other combinations, see Additional file 1: Table S4). A nominally significant ROC curve $(\mathrm{p}=.033)$ was obtained for this combination (Figure 1). The optimal point is at $\sim 80 \%$

Table 2 Genotype distribution, genotype frequencies, and minor allele frequencies for autism spectrum disorder (ASD), siblings, and control groups

\begin{tabular}{|c|c|c|c|c|}
\hline \multirow{2}{*}{$\begin{array}{l}\text { Polymorphism } \\
\text { HTTLPR triallelic }^{1}\end{array}$} & \multicolumn{3}{|c|}{ Genotype distribution (Genotype frequency) } & \multirow[t]{2}{*}{ MAF (Allele) } \\
\hline & ss & sl & II & \\
\hline ASD & $24(0.316)$ & $38(0.500)$ & $14(0.184)$ & $0.434(\mathrm{l})$ \\
\hline Siblings & $16(0.208)$ & $43(0.558)$ & $18(0.234)$ & $0.487(s)$ \\
\hline Controls & $22(0.248)$ & $51(0.526)$ & $24(0.247)$ & $0.490(s)$ \\
\hline HTR2A rs6311 2 & GG & GA & AA & A \\
\hline ASD & $21(0.276)$ & $34(0.447)$ & $21(0.276)$ & 0.500 \\
\hline Siblings & $23(0.295)$ & $35(0.449)$ & $20(0.256)$ & 0.481 \\
\hline Controls & $29(0.299)$ & $47(0.485)$ & $21(0.216)$ & 0.459 \\
\hline OXTR rs2301261 & CC & CT & TT & $\mathrm{T}$ \\
\hline ASD & $65(0.855)$ & $11(0.145)$ & 0 & 0.072 \\
\hline Siblings & $67(0.859)$ & $11(0.141)$ & 0 & 0.071 \\
\hline Controls & $84(0.848)$ & $15(0.152)$ & 0 & 0.076 \\
\hline OXTR rs53576 ${ }^{1}$ & AA & AG & GG & A \\
\hline ASD & $7(0.092)$ & $34(0.447)$ & $35(0.461)$ & 0.316 \\
\hline Siblings & $7(0.091)$ & $37(0.481)$ & $33(0.429)$ & 0.331 \\
\hline Controls & $9(0.093)$ & $33(0.340)$ & $55(0.567)$ & 0.263 \\
\hline OXTR rs2254298 & AA & AG & GG & A \\
\hline ASD & 0 & $12(0.158)$ & $64(0.842)$ & 0.079 \\
\hline Siblings & 0 & $13(0.167)$ & $65(0.833)$ & 0.083 \\
\hline Controls & 0 & $21(0.212)$ & $78(0.788)$ & 0.106 \\
\hline OXTR rs2268494 & AA & AT & $\mathrm{TT}$ & $A$ \\
\hline ASD & 0 & $13(0.171)$ & $63(0.829)$ & 0.086 \\
\hline Siblings & $1(0.013)$ & $9(0.115)$ & $68(0.872)$ & 0.071 \\
\hline Controls & 0 & 17 (0.172) & $82(0.828)$ & 0.086 \\
\hline
\end{tabular}

Abbreviations: $A S D$ autism spectrum disorder, OXTR oxytocin receptor, HTR2A serotonin receptor $2 \mathrm{~A}, H T T L P R$ serotonin-transporter-linked polymorphic region, $M A F$ minor allele frequency. ${ }^{1}$ Genotyping failed repeatedly for one sibling and two controls. ${ }^{2}$ Genotyping failed repeatedly for two controls. 
Table 3 Statistical association analysis between autism spectrum disorder (ASD) or its subgroups (atypical and Asperger) compared to controls or siblings with all six polymorphisms

\begin{tabular}{|c|c|c|c|c|}
\hline \multirow[b]{2}{*}{ Polymorphism } & \multicolumn{4}{|c|}{$p$ values } \\
\hline & AA vs. controls & AS vs. controls & ASD vs. controls & ASD vs. siblings \\
\hline \multicolumn{5}{|c|}{ Genotype frequencies } \\
\hline HTTLPR triallelic & 0.926 & 0.110 & 0.350 & 0.301 \\
\hline HTR2A rs6311 & 0.720 & 0.299 & 0.661 & 0.949 \\
\hline OXTR rs2301261 & 0.595 & 0.731 & 0.901 & 0.948 \\
\hline OXTR rs53576 & 0.524 & 0.280 & 0.334 & 0.914 \\
\hline OXTR rs2254298 & 0.460 & 0.592 & 0.363 & 0.883 \\
\hline OXTR rs2268494 & 0.870 & 0.974 & 0.991 & 0.388 \\
\hline \multicolumn{5}{|l|}{ Allele frequencies } \\
\hline HTTLPR triallelic & 0.708 & 0.040 & 0.160 & 0.168 \\
\hline HTR2A rs6311 & 0.591 & 0.410 & 0.446 & 0.736 \\
\hline OXTR rs2301261 & 0.609 & 0.743 & 0.905 & 0.950 \\
\hline OXTR rs53576 & 0.307 & 0.464 & 0.280 & 0.774 \\
\hline OXTR rs 2254298 & 0.486 & 0.614 & 0.390 & 0.888 \\
\hline OXTR rs2268494 & 0.877 & 0.975 & 0.991 & 0.623 \\
\hline \multicolumn{5}{|c|}{ Carrier frequencies [Carrier] } \\
\hline HTTLPR triallelic [s] & 0.787 & 0.108 & 0.319 & 0.451 \\
\hline HTTLPR triallelic [I] & 0.725 & 0.073 & 0.189 & 0.129 \\
\hline HTR2A rs6311 [C] & 0.949 & 0.158 & 0.362 & 0.780 \\
\hline HTR2A rs6311 [1] & 0.433 & 0.948 & 0.744 & 0.799 \\
\hline OXTR rs53576 [G] & 0.776 & 0.579 & 0.988 & 0.980 \\
\hline OXTR rs53576 [A] & 0.258 & 0.216 & 0.164 & 0.691 \\
\hline
\end{tabular}

In the subgroup analysis the three childhood autism were not included in either AA or AS subgroup. Abbreviations: AA atypical autism, $A S$ Asperger syndrome, ASD autism spectrum disorder, OXTR oxytocin receptor, HTR2A serotonin receptor $2 A$, HTTLPR serotonin-transporter-linked polymorphic region, vs. versus, Bold nominal significant.

sensitivity and $\sim 35 \%$ specificity or $\sim 35 \%$ sensitivity with $\sim 80 \%$ specificity. A genetic score cutoff of 4 or more, indicating more risk variants, resulted in an $\mathrm{OR}=$ 2.090 (95\% CI 1.045-4.179, $\mathrm{p}=.037$ ).

\section{Discussion}

ASD is a highly heritable neurodevelopmental disorder with suggested involvement of the serotonergic and oxytocinergic systems, but up to now, no clear association

Table 4 Results of the sibship disequilibrium test

\begin{tabular}{lcccc}
\hline Polymorphism & Allele & b & c & p \\
\hline HTTLRR triallelic & I & 8 & 12 & .503 \\
HTR2A rs6311 & A & 6 & 10 & .455 \\
OXTR rs2301261 & C & 5 & 1 & .219 \\
OXTR rs53576 & T & 6 & 8 & .791 \\
OXTR rs2254298 & G & 1 & 2 & 1.000 \\
OXTR rs2268494 & T & 2 & 4 & .688
\end{tabular}

Abbreviations: OXTR oxytocin receptor, HTR2A serotonin receptor $2 \mathrm{~A}, H T T L P R$ serotonin-transporter-linked polymorphic region. $b=$ mentioned allele more often transmitted to affected siblings. $c=$ mentioned allele more often transmitted to unaffected siblings. $p=$ two-tailed $p$ value. of polymorphisms with ASD has been found with a high effect size. Here, we evaluated children with HFA, their siblings, and controls using genotyping results for four SNPs in OXTR, one in HTR2A, and the HTTLPR length polymorphism. Our analysis showed that the $\mathrm{s}$ allele of the HTTLPR polymorphism was nominal significantly associated with HFA; however, it should be denoted that due to sample size the $\mathrm{p}$-value is rather borderline. We did not observe any significant association in the selected SNPs for the HTR2A and OXTR variants with HFA.

Regarding association with $H T R 2 A$, our findings are consistent with some previous studies $[26,28,32]$ reporting no association with autism. Only one study involving patients "rather severely affected from autism" [27] reported a link, but no information regarding IQ values was given.

Association studies of HTTLPR with ASD have led to contradictory results. Several have identified the $\mathrm{S}$ allele with ASD $[25,29,64,65]$ while others associated the L allele with ASD $[32,66,67]$ or found no association at all [68-71]. Our results rather support the first group. In our analysis of the HTTLPR, however, we used a 


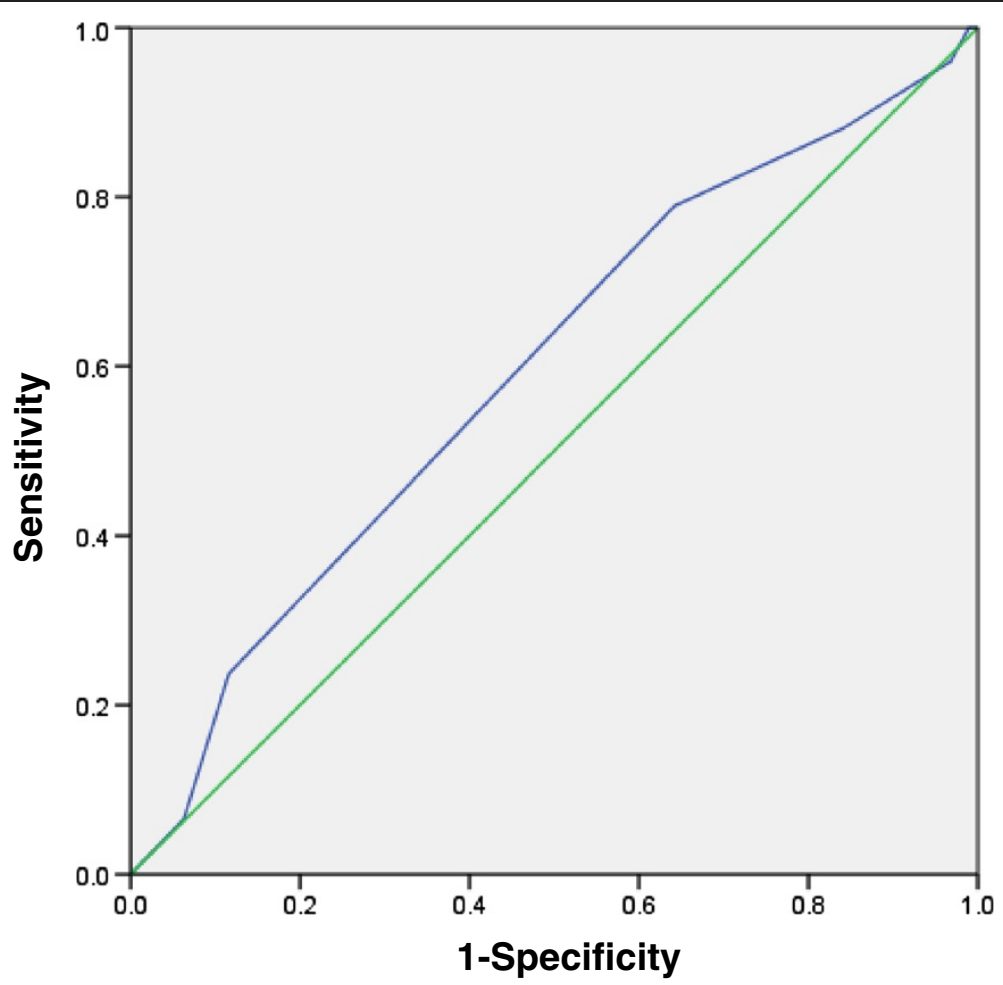

Figure 1 Receiver operating characteristic curve for the candidate polymorphism markers, serotonin transporter promoter length polymorphism (HTTLPR), serotonin receptor 2A (HTR2A) rs6311, oxytocin receptor (OXTR) rs2254298, and OXTR rs53576. AUC =0.595, $p=.033,95 \% \mathrm{Cl}: 0.509-0.681$. Sensitivity of $\sim 80 \%$ with specificity of $\sim 35 \%$ or sensitivity of $\sim 35 \%$ with specificity of $\sim 80 \%$.

triallelic mode in which the A and $\mathrm{G}$ alleles in the $\mathrm{L}$ allele were taken into account.

In accordance with previous reports [42,72] and a recent meta-analysis finding [44] in which no association between the OXTR polymorphisms rs53576 and rs2301261 with ASD was found, we also could not confirm one with HFA. Lerer et al. [40] identified an association between OXTR rs2268494 and autism diagnosis, but only when IQ was entered as a covariate. In our study, although our ASD population was stratified to IQ equal or larger than eighty, we could not confirm such a link. Concerning OXTR rs2254298, we also could not confirm an association with HFA, in contrast to several previous studies $[40,42,59,73]$. Nevertheless, our finding supports the recent meta-analysis in which no association could be proven accept for the biological functioning domain [44].

Although only one SNP singly was associated with HFA in this work, the gene-gene interaction study linked combinations of the tested polymorphisms with HFA. Similarly, such gene interaction study between HTTLPR and OXTR was reported in prediction of maternal sensitivity [74], pointing to their possible influence in social behavior. Furthermore, the ROC analysis showed that four of the tested SNPs together led to sensitivity of $80 \%$ but at the cost of low specificity $(35 \%)$ or vice versa.
The limitations of our study include the relatively small minor allele frequency for three of the OXTR polymorphisms and the sample size. Power analysis revealed that the power was sufficient only for a medium or large effect size. The power for small effect sizes (i.e., of 0.1) was below $20 \%$ for polymorphisms with two genotypes and about $30 \%$ if all three genotypes were present.

The strength of our study is the narrow phenotype regarding the intellectual and language ability and cognitive function. Most previous investigations have analyzed samples consisting of the complete spectrum of autism whereas in our investigation all individuals were diagnosed with HFA. In the past, $50-70 \%$ of autistic children were classified as intellectually disabled, but those with Asperger have, by definition, an IQ in the normal range [75] and typical language development.

As far as we know, only one study has investigated an association of OXTR in HFA, finding a weak association [72]. Of the 22 studied SNPs, one was nominally associated with autism diagnosis $(\mathrm{p}=.0185)$, which would not hold for Bonferroni correction for multiple testing [72]. Further research involving people with HFA has yielded evidence for an association with the oxytocin gene itself [76]; the CD38 gene [77], whose gene product is related to oxytocin secretion [78-80]; and the syntaxin 1A gene [81], whose gene product affects SERT function [82]. 
These findings indicate that some components of the serotonergic and oxytocinergic systems, other than those already extensively studied, might be involved in HFA. Additionally, similarly to the report by Carayol et al. [61], who combined the low-risk genes PITX, $A T P 2 B 2, S L C 25 A 12$, and $E N 2$, we could show that a combination of four polymorphisms (HTTLPR, HTR2A rs6311, and OXTR rs2254298 and rs53576) confers a nominal significant risk for HFA. This result points to the possibility that these genes play a role in ASD, probably in combination with additional risk genes that should be further explored.

\section{Conclusions}

In summary, many studies have found associations of OXTR, HTR2A, and SERT with ASD, but we could not confirm these with HFA except for a nominal association with the HTTLPR polymorphism. Our findings might be explained by the fact that HFA individuals have different symptoms from others with ASD and by the wide heterogeneity in the ASD population. Of interest, however, a combination of those polymorphisms resulted in nominal significant risk for HFA, pointing to the importance of a polygenetic rather than monogenetic context, in which each gene contributes to a very small fraction of the phenotype. Therefore, we suggest that future association studies should look into this aspect and examine various combinations of risk genes with HFA.

\section{Availability of supporting data}

The data sets supporting the results of this article are included within the article (and its additional files).

\section{Additional file}

Additional file 1: Table S1. Results of testing for deviation from Hardy-Weinberg equilibrium. Table S2. Allelic variation used in the calculation of genetic score under an additive model. Table S3. Gene-gene interactions and their associations with autism spectrum disorder (ASD). Table S4. Receiver operating characteristic curve analysis results for the different combinations of polygenetic risk for autism spectrum disorder (ASD)

\section{Abbreviations \\ ASD: Autism spectrum disorder; HFA: High functioning autism; 5-HT: Serotonin; HTR2A: Serotonin receptor 2A; HTTLPR: Promoter sequence of SERT contains a polymorphic region; ICD-10: International statistical classification of diseases and related health problems, 10th Revision; OR: Odds ratio; OXTR: Oxytocin receptor; ROC: Receiver operating characteristic; SERTSLC6A4: Serotonin transporter; SNP: Single nucleotide polymorphism; SSRIs: Selective serotonin reuptake inhibitors.}

\section{Competing interests}

The authors declare that they have no competing interests.

\section{Authors' contributions}

JN carried out the molecular genetic studies and performed the statistical analysis and drafted the manuscript. SW conceived of the study, and participated in its design and coordination and helped to draft the manuscript. EB conceived of the study, and participated in its design and recruitment of participants. RG participated in the recruitment of participants. EG participated in the design of the study and coordination and performed the statistical analysis and helped to draft the manuscript. All authors read and approved the final manuscript.

\section{Acknowledgements}

The work was partially supported by the "Studienstiftung Deutschland" and the "Bundesprogramm Chancengleichheit" 2009-2011 of the University Zürich. We thank Miryame Hofmann for her technical assistance as well as all the families and individuals for their participation.

Grant sponsor partially by the "Studienstiftung Deutschland" and the

"Bundesprogramm Chancengleichheit" 2009-2011 of the University Zürich; Grant number: none.

\section{Author details}

'University Clinics of Child and Adolescent Psychiatry (UCCAP), University of Zurich, Thurgauerstr. 39, CH-8050 Zurich, Switzerland. ${ }^{2}$ Neuroscience Center Zurich, University of Zurich and ETH Zurich, Zurich, Switzerland. ${ }^{3}$ Department of Experimental Psychology, University of Regensburg, Regensburg, Germany.

Received: 16 January 2014 Accepted: 22 January 2014

Published: 24 January 2014

\section{References}

1. American Psychiatric Association: DSM-IV. Diagnostic and Statistical Manual of Mental Disorders. 4th edition. Washington DC: APA; 1996.

2. American Psychiatric Association: DSM-V. Diagnostic and Statistical Manual of Mental Disorders. 5th edition. Washington DC: APA; 2013.

3. Williams JG, Higgins JP, Brayne CE: Systematic review of prevalence studies of autism spectrum disorders. Arch Dis Child 2006, 91(1):8-15.

4. Elsabbagh M, Divan G, Koh YJ, Kim YS, Kauchali S, Marcin C, Montiel-Nava C, Patel V. Paula CS, Wang C, et al: Global prevalence of autism and other pervasive developmental disorders. Autism Res 2012, 5(3):160-179.

5. Sun X, Allison C, Matthews FE, Sharp SJ, Auyeung B, Baron-Cohen S, Brayne $C$ : Prevalence of autism in mainland China, Hong Kong and Taiwan: a systematic review and meta-analysis. Mol Autism 2013, 4(1):7.

6. Hirtz D, Thurman DJ, Gwinn-Hardy K, Mohamed M, Chaudhuri AR, Zalutsky R: How common are the "common" neurologic disorders? Neurology 2007, 68(5):326-337.

7. Bailey A, Le Couteur A, Gottesman I, Bolton P, Simonoff E, Yuzda E, Rutter M: Autism as a strongly genetic disorder: evidence from a British twin study. Psychol Med 1995, 25(1):63-77.

8. Freitag CM: Genetic risk in autism: new associations and clinical testing. Expert opinion on medical diagnostics 2011, 5(4):347-356.

9. Hallmayer J, Cleveland S, Torres A, Phillips J, Cohen B, Torigoe T, Miller J, Fedele A, Collins J, Smith K, et al: Genetic heritability and shared environmental factors among twin pairs with autism. Arch Gen Psychiatry 2011, 68(11):1095-1102.

10. Robinson EB, Koenen KC, McCormick MC, Munir K, Hallett V, Happe F, Plomin R, Ronald A: A multivariate twin study of autistic traits in 12year-olds: testing the fractionable autism triad hypothesis. Behavior Genet 2012, 42(2):245-255.

11. Curatolo P, Porfirio MC, Manzi B, Seri S: Autism in tuberous sclerosis. Eur J Paediatr Neurol 2004, 8(6):327-332.

12. LaSalle JM, Yasui DH: Evolving role of MeCP2 in Rett syndrome and autism. Epigenomics 2009, 1(1):119-130.

13. Freitag CM: The genetics of autistic disorders and its clinical relevance: a review of the literature. Mol Psychiatry 2007, 12(1):2-22.

14. Dolen G, Darvishzadeh A, Huang KW, Malenka RC: Social reward requires coordinated activity of nucleus accumbens oxytocin and serotonin. Nature 2013, 501(7466):179-184.

15. Hranilovic D, Bujas-Petkovic Z, Vragovic R, Vuk T, Hock K, Jernej B: Hyperserotonemia in adults with autistic disorder. J Autism Dev Disord 2007, 37(10):1934-1940.

16. McDougle CJ, Naylor ST, Cohen DJ, Aghajanian GK, Heninger GR, Price LH: Effects of tryptophan depletion in drug-free adults with autistic disorder. Arch Gen Psychiatry 1996, 53(11):993-1000.

17. Makkonen I, Riikonen R, Kokki H, Airaksinen MM, Kuikka JT: Serotonin and dopamine transporter binding in children with autism determined by SPECT. Dev Med Child Neurol 2008, 50(8):593-597. 
18. Nakamura K, Sekine $Y$, Ouchi $Y$, Tsujii M, Yoshikawa E, Futatsubashi M, Tsuchiya KJ, Sugihara G, Iwata Y, Suzuki K, et al: Brain serotonin and dopamine transporter bindings in adults with high-functioning autism. Arch Gen Psychiatry 2010, 67(1):59-68.

19. Murphy DG, Daly E, Schmitz N, Toal F, Murphy K, Curran S, Erlandsson K, Eersels J, Kerwin R, Ell P, et al: Cortical serotonin 5-HT2A receptor binding and social communication in adults with Asperger's syndrome: an in vivo SPECT study. Am J Psychiatry 2006, 163(5):934-936.

20. Gordon CT, State RC, Nelson JE, Hamburger SD, Rapoport JL: A doubleblind comparison of clomipramine, desipramine, and placebo in the treatment of autistic disorder. Arch Gen Psychiatry 1993, 50(6):441-447.

21. Kolevzon A, Mathewson KA, Hollander E: Selective serotonin reuptake inhibitors in autism: a review of efficacy and tolerability. J Clin Psychiatry 2006, 67(3):407-414

22. McDougle CJ, Naylor ST, Cohen DJ, Volkmar FR, Heninger GR, Price LH: A double-blind, placebo-controlled study of fluvoxamine in adults with autistic disorder. Arch Gen Psychiatry 1996, 53(11):1001-1008.

23. Dove D, Warren Z, McPheeters ML, Taylor JL, Sathe NA, Veenstra-VanderWeele $\mathrm{J}$ : Medications for adolescents and young adults with autism spectrum disorders: a systematic review. Pediatrics 2012, 130(4):717-726.

24. Huang $\mathrm{CH}$, Santangelo SL: Autism and serotonin transporter gene polymorphisms: a systematic review and meta-analysis. American journal of medical genetics Part B, Neuropsychiatric genetics: the official publication of the International Society of Psychiatric Genetics 2008, 147B(6):903-913.

25. Kistner-Griffin E, Brune CW, Davis LK, Sutcliffe JS, Cox NJ, Cook EH Jr: Parent-of-origin effects of the serotonin transporter gene associated with autism. Am J Med Genet B Neuropsychiatr Genet 2011, 156(2):139-144.

26. Guhathakurta S, Singh AS, Sinha S, Chatterjee A, Ahmed S, Ghosh S, Usha R: Analysis of serotonin receptor $2 A$ gene (HTR2A): association study with autism spectrum disorder in the Indian population and investigation of the gene expression in peripheral blood leukocytes. Neurochem Int 2009, 55(8):754-759

27. Hranilovic D, Blazevic S, Babic M, Smurinic M, Bujas-Petkovic Z, Jernej B: 5-HT2A receptor gene polymorphisms in Croatian subjects with autistic disorder. Psychiatry Res 2010, 178(3):556-558.

28. Veenstra-VanderWeele J, Kim SJ, Lord C, Courchesne R, Akshoomoff N, Leventhal BL, Courchesne E, Cook EH Jr: Transmission disequilibrium studies of the serotonin 5-HT2A receptor gene (HTR2A) in autism. Am J Med Genet 2002, 114(3):277-283.

29. Devlin B, Cook EH Jr, Coon H, Dawson G, Grigorenko EL, McMahon W Minshew N, Pauls D, Smith M, Spence MA, et al: Autism and the serotonin transporter: the long and short of it. Mol Psychiatry 2005, 10(12):1110-1116.

30. Hu XZ, Lipsky RH, Zhu G, Akhtar LA, Taubman J, Greenberg BD, Xu K, Arnold $P D$, Richter MA, Kennedy JL, et al: Serotonin transporter promoter gainof-function genotypes are linked to obsessive-compulsive disorder. Am J Hum Genet 2006, 78(5):815-826.

31. Lesch KP, Bengel D, Heils A, Sabol SZ, Greenberg BD, Petri S, Benjamin J, Muller CR, Hamer DH, Murphy DL: Association of anxiety-related traits with a polymorphism in the serotonin transporter gene regulatory region. Science 1996, 274(5292):1527-1531.

32. Cho $H$, Yoo HJ, Park M, Lee YS, Kim SA: Family-based association study of 5-HTTLPR and the 5-HT2A receptor gene polymorphisms with autism spectrum disorder in Korean trios. Brain Res 2007, 1139:34-41.

33. Green L, Fein D, Modahl C, Feinstein C, Waterhouse L, Morris M: Oxytocin and autistic disorder: alterations in peptide forms. Biol Psychiatry 2001, 50(8):609-613.

34. Modahl C, Green L, Fein D, Morris M, Waterhouse L, Feinstein C, Levin H: Plasma oxytocin levels in autistic children. Biol Psychiatry 1998, 43(4):270-277.

35. Hollander E, Bartz J, Chaplin W, Phillips A, Sumner J, Soorya L, Anagnostou E, Wasserman S: Oxytocin increases retention of social cognition in autism. Biol Psychiatry 2007, 61(4):498-503.

36. Hollander E, Novotny S, Hanratty M, Yaffe R, DeCaria CM, Aronowitz BR, Mosovich S: Oxytocin infusion reduces repetitive behaviors in adults with autistic and Asperger's disorders. Neuropsychopharmacology 2003, 28(1):193-198.

37. Andari E, Duhamel JR, Zalla T, Herbrecht E, Leboyer M, Sirigu A: Promoting social behavior with oxytocin in high-functioning autism spectrum disorders. Proc Natl Acad Sci USA 2010, 107(9):4389-4394.

38. Guastella AJ, Einfeld SL, Gray KM, Rinehart NJ, Tonge BJ, Lambert TJ, Hickie IB: Intranasal oxytocin improves emotion recognition for youth with autism spectrum disorders. Biol Psychiatry 2010, 67(7):692-694.
39. Hammock EA, Young LJ: Oxytocin, vasopressin and pair bonding: implications for autism. Philos Trans R Soc Lond B Biol Sci 2006, 361(1476):2187-2198.

40. Lerer E, Levi S, Salomon S, Darvasi A, Yirmiya N, Ebstein RP: Association between the oxytocin receptor (OXTR) gene and autism: relationship to Vineland Adaptive Behavior Scales and cognition. Mol Psychiatry 2008, 13(10):980-988.

41. Campbell DB, Datta D, Jones ST, Batey Lee E, Sutcliffe JS, Hammock EA, Levitt P: Association of oxytocin receptor (OXTR) gene variants with multiple phenotype domains of autism spectrum disorder. J Neurodev Disord 2011, 3(2):101-112.

42. Jacob S, Brune CW, Carter CS, Leventhal BL, Lord C, Cook EH Jr: Association of the oxytocin receptor gene (OXTR) in Caucasian children and adolescents with autism. Neurosci Lett 2007, 417(1):6-9.

43. Anney R, Klei L, Pinto D, Regan R, Conroy J, Magalhaes TR, Correia C, Abrahams BS, Sykes N, Pagnamenta AT, et al: A genome-wide scan for common alleles affecting risk for autism. Hum Mol Genet 2010, 19(20):4072-4082.

44. Bakermans-Kranenburg MJ, van ljzendoorn MH: A sociability gene? Meta-analysis of oxytocin receptor genotype effects in humans. Psychiatr Genet 2013:PMID: 23921259 [Epub ahead of print].

45. Hammock E, Veenstra-VanderWeele J, Yan Z, Kerr TM, Morris M, Anderson GM, Carter CS, Cook EH, Jacob S: Examining autism spectrum disorders by biomarkers: example from the oxytocin and serotonin systems. J Am Acad Child Adolesc Psychiatry 2012, 51(7):712-721. e711.

46. Thanseem I, Anitha A, Nakamura K, Suda S, Iwata K, Matsuzaki H, Ohtsubo M, Ueki T, Katayama T, Iwata $Y$, et al: Elevated transcription factor specificity protein 1 in autistic brains alters the expression of autism candidate genes. Biol Psychiatry 2012, 71(5):410-418.

47. Rühl D, Bölte S, Feineis-Matthews S, Poustka F: Diagnostische Beobachtungsskala für Autistische Störungen; Deutsche Fassung der Autism Diagnostic Observation Schedule (ADOS). Switzerland: Verlag Hans Huber; 2004

48. Bölte S, Rühl D, Schmötzer G, Poustka F: Diagnostisches Interview für Autismus - Revidiert (ADI-R); Deutsche Fassung des Autism Diagnostic Interview - Revised. Switzerland: Verlag Hans Huber; 2006.

49. Noterdaeme M, Wriedt $E$, Hohne C: Asperger's syndrome and highfunctioning autism: language, motor and cognitive profiles. Eur Child Adolesc Psychiatry 2010, 19(6):475-481.

50. Carpenter LA, Soorya L, Halpern D: Asperger's syndrome and high-functioning autism. Pediatr Ann 2009, 38(1):30-35.

51. World Health Organization: ICD-10: International statistical classification of diseases and related health problems (10th Rev. ed.) 10th edition. New York, NY, USA: World Health Organization; 2008.

52. Arbeitsgruppe Kinder- Jugendlichen- und Familiendiagnostik: Child Behavior Checklist (CBCL); Elternfragebogen über das Verhalten von Kindern und Jugendlichen. In 2nd edition. Edited by Döpfner M, Plück J, Bölte S, Lenz K, Melchers P, Heim K. Köln: Arbeitsgruppe Kinder-, Jugendund Familiendiagnostik (KJFD; 1998.

53. Bölte S, Poustka F: Skala zur Erfassung sozialer Reaktivität Dimensionale Autismus-Diagnostik; Deutsche Fassung der Social Responsiveness Scale (SRS). In Edited by Constantino J, Gruber C. Bern, Switzerland: Verlag Hans Huber; 2007

54. Bölte S, Poustka F: Fragebogen zur Sozialen Kommunikation - AutismusScreening; Deutsche Fassung des Social Communication Questionnaire (SCQ). Verlag Hans Huber: Bern, Switzerland; 2006.

55. Conners C: Conners 3TM. 3rd edition. Toronto, Ontario, Canada: Multi-Health Systems; 2008

56. Döpfner M, Lehmkuhl G: FBB-HKS [Rating-scale for Hyperkinetic Disorder from the Diagnostic System for Mental Disorders in Childhood and Adolescence according to ICD-10 and DSM-IV (DISYPS-KJ)]. 2nd edition. Hofgrefe: Göttingen, Germany; 2000

57. Tellegen P, Winkel M, Laros J: Snijders Oomen Non-verbal Intelligence Test Revised (SON-R). Hofgrefe-Verlag: Göttingen, Germany; 2003.

58. Weiss R: CFT 20-R: Grundintelligenztest Skala 2-Revision. Göttingen, Germany: Hofgrefe-Verlag; 2006.

59. Wu S, Jia M, Ruan Y, Liu J, Guo Y, Shuang M, Gong X, Zhang Y, Yang X, Zhang D: Positive association of the oxytocin receptor gene (OXTR) with autism in the Chinese Han population. Biol Psychiatry 2005, 58(1):74-77

60. Horvath S, Laird NM: A discordant-sibship test for disequilibrium and linkage: no need for parental data. Am J Hum Genet 1998, 63(6):1886-1897. 
61. Carayol J, Schellenberg GD, Tores F, Hager J, Ziegler A, Dawson G: Assessing the impact of a combined analysis of four common low-risk genetic variants on autism risk. Mol Autism 2010, 1(1):4.

62. Faul F, Erdfelder E, Buchner A, Lang AG: Statistical power analyses using G*Power 3.1: tests for correlation and regression analyses. Behav Res Methods 2009, 41(4):1149-1160.

63. Faul F, Erdfelder E, Lang AG, Buchner A: G*Power 3: a flexible statistical power analysis program for the social, behavioral, and biomedical sciences. Behav Res Methods 2007, 39(2):175-191.

64. Arieff Z, Kaur M, Gameeldien H, van der Merwe L, Bajic VB: 5-HTTLPR polymorphism: analysis in South African autistic individuals. Hum Biol 2010, 82(3):291-300

65. Conroy J, Meally E, Kearney G, Fitzgerald M, Gill M, Gallagher L: Serotonin transporter gene and autism: a haplotype analysis in an Irish autistic population. Mol Psychiatry 2004, 9(6):587-593.

66. Coutinho AM, Oliveira G, Morgadinho T, Fesel C, Macedo TR, Bento C, Marques C, Ataide A, Miguel T, Borges $L$, et al: Variants of the serotonin transporter gene (SLC6A4) significantly contribute to hyperserotonemia in autism. Mol Psychiatry 2004, 9(3):264-271.

67. Yirmiya N, Pilowsky T, Nemanov L, Arbelle S, Feinsilver T, Fried I, Ebstein RP Evidence for an association with the serotonin transporter promoter region polymorphism and autism. Am J Med Genet 2001, 105(4):381-386.

68. Betancur C, Corbex M, Spielewoy C, Philippe A, Laplanche JL, Launay JM, Gillberg C, Mouren-Simeoni MC, Hamon M, Giros B, et al: Serotonin transporter gene polymorphisms and hyperserotonemia in autistic disorder. Mol Psychiatry 2002, 7(1):67-71.

69. Ma DQ, Rabionet R, Konidari I, Jaworski J, Cukier HN, Wright HH, Abramson RK, Gilbert JR, Cuccaro ML, Pericak-Vance MA, et al: Association and gene-gene interaction of SLC6A4 and ITGB3 in autism. Am J Med Genet B Neuropsychiatr Genet 2010, 153B(2):477-483.

70. Persico AM, Pascucci T, Puglisi-Allegra S, Militerni R, Bravaccio C, Schneider C, Melmed R, Trillo S, Montecchi F, Palermo M, et al: Serotonin transporter gene promoter variants do not explain the hyperserotoninemia in autistic children. Mol Psychiatry 2002, 7(7):795-800.

71. Ramoz N, Reichert JG, Corwin TE, Smith CJ, Silverman JM, Hollander E, Buxbaum JD: Lack of evidence for association of the serotonin transporter gene SLC6A4 with autism. Mol Psychiatry 2006, 60(2):186-191.

72. Wermter AK, Kamp-Becker I, Hesse P, Schulte-Korne G, Strauch K, Remschmidt $\mathrm{H}$ : Evidence for the involvement of genetic variation in the oxytocin receptor gene (OXTR) in the etiology of autistic disorders on high-functioning level. Am J Med Genet B Neuropsychiatr Genet 2010, $153 \mathrm{~B}(2): 629-639$.

73. Liu X, Kawamura Y, Shimada T, Otowa T, Koishi S, Sugiyama T, Nishida H, Hashimoto O, Nakagami R, Tochigi M, et al: Association of the oxytocin receptor (OXTR) gene polymorphisms with autism spectrum disorder (ASD) in the Japanese population. J Hum Genet 2010, 55(3):137-141.

74. Bakermans-Kranenburg MJ, van ljzendoorn MH: Oxytocin receptor (OXTR) and serotonin transporter (5-HTT) genes associated with observed parenting. Soc Cogn Affect Neurosci 2008, 3(2):128-134.

75. Howlin P: Outcome in high-functioning adults with autism with and without early language delays: implications for the differentiation between autism and Asperger syndrome. J Autism Dev Disord 2003, 33(1):3-13.

76. Chakrabarti B, Dudbridge F, Kent L, Wheelwright S, Hill-Cawthorne G, Allison C, Banerjee-Basu S, Baron-Cohen S: Genes related to sex steroids, neural growth, and social-emotional behavior are associated with autistic traits, empathy, and Asperger syndrome. Autism Res 2009, 2(3):157-177.

77. Munesue T, Yokoyama S, Nakamura K, Anitha A, Yamada K, Hayashi K, Asaka T, Liu HX, Jin D, Koizumi K, et al: Two genetic variants of CD38 in subjects with autism spectrum disorder and controls. Neurosci Res 2010, 67(2):181-191.

78. Ebstein RP, Israel S, Lerer E, Uzefovsky F, Shalev I, Gritsenko I, Riebold M, Salomon S, Yirmiya N: Arginine vasopressin and oxytocin modulate human social behavior. Ann N Y Acad Sci 2009, 1167:87-102.

79. Higashida H, Yokoyama S, Huang JJ, Liu L, Ma WJ, Akther S, Higashida C, Kikuchi M, Minabe Y, Munesue T: Social memory, amnesia, and autism: brain oxytocin secretion is regulated by $N A D+$ metabolites and single nucleotide polymorphisms of CD38. Neurochem Int 2012, 61(6):828-838.

80. Jin D, Liu HX, Hirai H, Torashima T, Nagai T, Lopatina O, Shnayder NA, Yamada K, Noda M, Seike T, et al: CD38 is critical for social behaviour by regulating oxytocin secretion. Nature 2007, 446(7131):41-45.
81. Nakamura K, Anitha A, Yamada K, Tsujii M, Iwayama Y, Hattori E, Toyota T, Suda S, Takei N, Iwata Y, et al: Genetic and expression analyses reveal elevated expression of syntaxin 1A ( STX1A) in high functioning autism. Int J Neuropsychopharmacol 2008, 11(8):1073-1084.

82. Quick MW: Role of syntaxin 1A on serotonin transporter expression in developing thalamocortical neurons. Int J Dev Neurosci 2002, 20(3-5):219-224.

doi:10.1186/2049-9256-2-1

Cite this article as: Nyffeler et al:: Association study in siblings and casecontrols of serotonin- and oxytocin-related genes with high functioning autism. Journal of Molecular Psychiatry 2014 2:1.

\section{Submit your next manuscript to BioMed Central and take full advantage of:}

- Convenient online submission

- Thorough peer review

- No space constraints or color figure charges

- Immediate publication on acceptance

- Inclusion in PubMed, CAS, Scopus and Google Scholar

- Research which is freely available for redistribution 